\author{
Александар М. МИЛАНОВИЋ \\ Универзитет у Београду \\ Филолошки факултет
}

Оригинални научни рад

Примљен: 12. 02. 2019.

Прихваћен: 14. 02. 2019.

\title{
СТАТУС ОНИМА СТРАНОГ ПОРЕКЛА У СЛАВЕНОСРПСКОМ ЈЕЗИКУ*
}

\begin{abstract}
У раду се анализира развој облика онима страног порекла у славеносрпским публицистичким текстовима, са посебним освртом на графијска, ортографска, фонетско-фонолошка, деривациона и лексичка колебања. Конкуренција и коегзистенција облика сагледавају се и на социолингвистичком и стилистичком плану, а аутор се због богатства различитих облика залаже за израду дијахронијског речника онима у славеносрпској епохи (од средине 18. до средине 19. века).

Кључне речи: славеносрпски језик, оним, етноним, конкуренција, вернакуларизација, дублетност, публицистички стил, панславизам, дијахронијски речник онима.
\end{abstract}

1. Промена форме онима. Није непознато да форме многих онима који су потврђени у славеносрпским текстовима могу изазивати бројне недоумице код мање упућених читалаца. Тако један пример из тадашњих новина указује на више проблема код специфичног именовања народа настањених ван нашега језичког простора: Іошть онда є владьтелство Португизе, Алгирце и Негре натрагъ послало (Новине сербске, 1813, 174). Форме Португизи и Алгирии, као и многе друге, нису карактеристичне са савремени српски језик. Архаичне су, али прозирног значења. Пример, међутим, због речи Негри може и теоријско-методолошки закомпликовати статус онима у 18. и 19. веку. Културолошка адаптација нових појмова и лексема овде, очито, још није била извршена до краја. ${ }^{1}$ Сличну појаву запажамо и у примерима Bapварска, Варварија и Берберија: Варварска СВ 1794/397;2 Варварїа африканска

\footnotetext{
*aleksandar.jus@gmail.com

** Рад је настао у оквиру пројекта 178006 Српски језик и његови ресурси; теорија, опис и примене, који финансира Министарство науке, просвете и технолошког развоја Републике Србије.

${ }^{1}$ Уп. примере: Чрнцы (чрни люди) [...] страшно се заклели, да све бълце поубїяю НС 1816/637.

${ }^{2}$ Реч је наведена верзалом у наслову, а у тој су се позицији у СВ наводила имена држава.
} 
(Берберїа) НС 1816/692. Ову тему остављамо за лингвокултуролошка истраживања, у која би спадала и тема потенцијалног утицаја фолклорног језика при навођењу онима: у Лондону граду СВ 1794/204, Изъ Мемела града СВ 1794/207 и сл., као и тема (не)познатости онима широј публици тј. читаоцима и језичких маркера који уводе нове јединице: Унтерлайтнантъ именемъ Менгенъ СВ 1794/201, у мъсту Тулузъ зовомомъ СВ 1794/235 и сл.

Често су у литератури коментарисани многи примери промене форме онима кроз историју српског језика, па се тако пореклу и развоју онима враћа чак и савремени правопис, приручник намењен најширој корисничкој публици. ${ }^{3}$ Међутим, мањак потврда управо из славеносрпске епохе доприноси и недовољно прецизним описима савременог стања. ${ }^{4}$

Захваљујући окретању српске културе ка западноевропској, као и развоју публицистике који је из те промене следио, многи од онима су из страних у српски језик почели продирати управо у славеносрпској епохи. Како су, међутим, славеносрпски текстови остали махом ван грађе за постојеће српске речнике, ово ономастичко благо, које посредно може указати и на различите књижевнојезичке тенденције, још увек није сакупљено. Иако се за Речник славеносрпског језика, чија израда је у току, врши тотална ексцерпција грађе, оними ће и у овом лексикографском остварењу бити изостављени (ОС 2017: 18).

2. Дистрибуција онима према стилу и жанру текста. У славеносрпској епохи је нагло растао број стилова и жанрова српске писмености. Оними су, наравно, навођени у делима писаним различитим стиловима (књижевним и научним делима, школским уџбеницима, административним списима, дневницима, приватним писмима и др.), али су најбројнији и најразноврснији у публицистичким текстовима: дневним новинама, часописима, алманасима, забавницима и календарима. Презасићеност новинских прилога различитим онимима истакао је на самим почецима српске журналистике и Вук Караџић (1968: 15): „Штил э сваки новина обично сув и опор, а особито сад у време войне кад се готово цЊле из датума, и из имена собствени, состое”. Стога смо за корпус овога рада изабрали прве српске дневне новине: Сербскія повседневнія новины (у даљем тексту: $\mathrm{CH}$ ), које су излазиле од 1791. до 1792, ${ }^{5}$ Славенно-сербскїя вђдомости (у даљем тексту: СВ), које су излазиле од 1792. до 1794, и Новине Сербске (у даљем тексту: НС), ${ }^{6}$ које су у излазиле од 1813. до 1822. године. Све наведене новине излазиле су у Бечу, у укупном периоду дужем од 30 година. Већ и површан поглед на језик у њима показује не само високу фреквенцију онима већ и неустаљеност форме многих од њих,

\footnotetext{
${ }^{3}$ Уп.: „Истанбул (потиснут је, без уверљ. разлога, фонетизам са -мб-, уп. трад. Стамбол, презиме Стамболић; није било ни разлога да се у срп. култури истисне назив Цариград, уп. друкчије у избору између Беч - Вијена, Рим - Рома" (ПМС 2014: 333).

${ }^{4}$ УП. нпр. опис суфикса -ёз у савременом српском стандардном језику (Клајн 2003: 227).

${ }^{5}$ Новине су од 15. броја, 1791. године, скратиле име избацивањем речи повседневнія у Сербскія новины.

${ }^{6}$ Новине су промениле име ортографском интервенцијом од 1. броја 1816, од када место сербске пише србске.
} 
нарочито при фонетској адаптацији страних онима, као и честе облике који су посве различити од данашњих.

3. Колебање форме онима. Наведеном феномену конкуренције и коегзистенције форми онима није посвећено много радова. У двема студијама Александра Албијанића, о деклинацији страних личних имена у НС из 1813. г. (Албијанић 1979) и о истом феномену на ширем корпусу $(\mathrm{CH}$; $\mathrm{CB}$ и $\mathrm{HC}$ из 1814) (Албијанић 1984), видљива је морфолошка тенденција: у СН и СВ оними са крајњим $-u,-y,-\bar{e}$ и $-\bar{o}$ остају углавном непроменљиви, али су оне већ у НС скоро по правилу деклинабилне, а финални вокали осећају се као део основе (Албијанић 1984: 74). ${ }^{7}$ Друга занимљива морфолошка питања аутор није покренуо. Колебање облика онима, међутим, није видљиво само на морфолошкој равни. Циљеви овога рада стога јесу да се уоче односи међу онимима потврђеним у слс. новинским текстовима, да се издвоје тенденције при њиховим променама и да се кроз анализу типичних примера конкуренције и коегзистенције форми укаже научној јавности како је потребно израдити дијахронијски Речник онима у славеносрпском језику као додатни пројекат уз Речник славеносрпског језика.

4. Графијско-ортографска колебања. Као и сву другу лексику у овом периоду, ониме прате карактеристична графијско-ортографска колебања, понекад и више њих у истом примеру, нпр.: Изъ Бриссла СВ 1794/165 : Изъ Брысла НС 1817/203. Најчешће су у питању већ познате и описане графијско-ортографске несистемности при обележавању група са интервокалним /j/ (Вандїанцы НС 1815/491, 506 : Вандїянцы НС 1815/491), алтернативно писање вокала /i/ (Парисъ СВ 1794/112 : Парїзъ СВ 1794/215), обележавање /d/ (Маћарска СВ 1794/211, 224, Мадьарска НC 1818/108), удвојено писање графема (Изъ Хага СВ 1792/60 : У Хаагу СВ 1792/69, Велїнтнъ НС 1813/3, 9 : Веллїнтну НС 1813/3), писање грецизама (Еrропу НС 1813/84 : Европа НС $1814 / 63)$ и сл.

Занимљиво је да у страним онимима постојеће графеме могу добијати и нове функције, нпр. да ближе дочарају оригинални изговор или графију, као у случају јерија (Дысселдорфа НС 1814/96б, Дыжонъ НС 1815/745, Брысла НС 1816/275, Цыриху НС 1817/239). Такође, у овом засебном лексичком слоју графеме могу имати и мање распрострањену гласовну вредност, као у случају јата са вредношћу /je/: Валенсњнъ НС 1816/258, Сърре Леоне НС 1816/569. Коначно, страни оними понекад и ортографски следе оригинално писање: измежду воде Саале НС 1813/165, У Хаагу НС 1819/65 и сл. ${ }^{8}$

5. Фонетско-фонолошка колебања. Необично велики број страних онима у другачијем је фонетском лику од данашњих, чему су суштински доприносили различити фактори, често укрштени - утицај оригиналне графије, уредниково, новинарево или преводиочево непознавање појединих страних језика (нпр. енглеског, француског, шпанског и сл.), другачија акустичка сли-

\footnotetext{
${ }^{7}$ Како је и у НС у периоду 1815-1821. ова слика готово иста као и до 1815, питање морфолошког колебања у овом раду ћемо прескочити.

${ }^{8}$ УП. и примере са губљењем сугласника, различите само на ортографском плану: Шотландцы СВ 1794/32 : Шотланцы НС 1816/453.
} 
ка створена слушањем онима, промена облика онима у самом страном језику или утицај језика посредника (углавном немачког): Шарлероа (Шарлероа СВ 1794/193), Дублин (Дублину СВ 1794/204, Дублину НС 1817/172), Весарабија (Вессарабій НС 1814/217), Гивралтар (Гивралтару НС 1817/281, Гивралтара НС 1819/547), Вуенос-Аирес (Вуенос-Аиресь НС 1818/19), Алгир (Алгиръ НС 1817/202, Алгира НС 1818/178), Версаиљ (Версаилю НС 1817/212), Лиљ (Лиля НС 1817/270), Рио-Јанеиро (Рїя-Янеира НС 1817/276), Чина (Чину НC 1818/184), Тошкана (Тошкана НС 1819/331), Венесуела (Венесуеле НС 1819/567), Валадолид (Валладолиду НС 1816/350, Валадолиду НС 1819/467), Штокхолм (Штокхолмъ НС 1817/238, Штокхолма НС 1817/229), Ливрпул (Ливрпула НС 1817/212) и др. Сви наведени фактори узроковали су и бројне конкурентне форме истих онима, а нису ретки ни конкуренти са више дистинктивних гласовних црта (Букорестъ СН 1791/10 : Б8к8рестъ СН 1791/32, Букуресть НС 1820/658 : Букаресть НС 1818/631; Штутгардь НС 1816/322 : Стутгарту НС 1816/348 и сл.).

Многе гласовне опозиције из наше ономастичке грађе потврђене су у литератури и на примерима других позајмљеница: ${ }^{9}$ Аустрија : Австрија (Аустрїа CB 1792/5, Аустрїа CB 1793/25, Аустрїа НC 1817/871 : Австрїя НС 1817/255, Австрїє НС 1818/667, Австрїя НС 1819/489), Австралија : Аустралија (Австралїа НС 1817/603 : Аустралїи НС 1818/26), Генува : Генуа (изъ Ген8ве СН 1792/342, Генуве СВ 1794/308 : Генуе СВ 1792/60, Генуе СВ 1794/349), Триест : Трсm (Трїеста СВ 1793/243, Трїеста НС 1818/756 : Трсть НC 1818/203), Брасилија : Бразилија (Брасїлїа НС 1814/796, Брасилїа НС 1816/89 : Бразилїа НС 1816/959, Бразилїя НС 1818/211, 267), Асија : Азија (Азїе НС 1817/171 : Асcїа НС 1818/111), Парис : Париз (Парисъ СВ 1794/112 : Паризъ СН 1791/42, Парїзъ СВ 1794/215), Полска : Пољска (Полски СН 1791/26, Полска СН 1791/41, 91, Полска СВ 1793/23, Полску СВ 1794/180 : Польске НС 1814/190, Польска НС 1817/164), Мадрит : Мадрид (Мадрить СН 1791/37, Мадрить СВ 1792/62, Мадрита СВ 1792/56 : Мадрїда СН 1791/63, Мадриду НС 1817/228), Неапол: Неапољ (Неаполь СВ 1794/243, у Неаплу НС 1813/46: Неаполя СВ 1792/14, у Неаполю СВ 1792/15, у Неаплю НС 1813/46), Мацарска : Мађарска (Мачжарска НС 1817/581 : Маћарска СВ 1794/211, 224, Мадьарска НС 1818/108), Росија : Русија (Россїа СН 1791/31, Poccïa CB 1794/24, Poccïa HC 1817/153, Poccïa HC 1818/546 : Pycïa НС 1818/575, 586, 595, 601), Норвешка : Норвегска (Норвежска НС 1813/20, Норвежску НС 1813/20 : Норвегска НС 1817/235, Норвегску НС 1814/66), Мексико : Мехико : Мекхико (Мексико НС 1816/437 : Мехика НС 1819/489 : Мекхика НС 1818/38), Немецка : Немачка (Ньмецка НС 1814/63 : Немачка НС 1817/164), Инглеска : Енглеска (Инглезске НС 1814/3 : Енглезска НС 1814/574), Англез : Инглез : Енглез (Англези СВ 1793/243, Англезе СВ 1794/52, Англези СВ 1794/164 : Инглези НС 1814/62 : Енглезъ НС 1816/610, Енглези НС 1817/146, Енглези НС 1818/176), Кадикс : Кадис : Кадић (Ка-

${ }^{9}$ УП. Милановић 2014 и литературу у тој монографији. 
диксъ НС 1814/1158, Кадикса НС 1815/28 : Кадисъ НС 1816/929, Кадиса НС 1817/247 : Кадићъ НС 1819/17) итд. ${ }^{10}$

6. Творбена колебања. За историју књижевног језика свакако су најзанимљивији примери творбе онима. Оними страног порекла показују конкуренцију суфикса (Ћорић 2008: 221-225), домаћих и страних, али и пуристичку тежњу ка вернакуларизацији (понародњавању) страних облика.

6.1. У деривацији етника потврђени су бројни данас архаични облици, попут форми са нултим суфиксом: Швед (Шведи СН 1791/35, Шведи НС 1814/708, у Шведа НС 1817/229), Прајз (Прайзу СВ 1794/164, Прайзи НС $1814 / 62$ ), итд. Творбени дублети указују и на конкуренцију суфикса (Р8сси CH 1791/17, Россы НС 1813/1 Росси НС 1813/20: Россїаны НC 1813/1, Россїанъ НC 1813/136, Россїана НС 1813/20, Россїани НС 1815/44; Туны СњВ 1794/397 : Тунисцы НC 1816/457; Тулузчана НC 1814/370 : Тулузаца НC 1816/398; Елсесчана НС 1814/383, Елсесчани НС 1814/515 : Елзашанинъ НС $1819 / 437$ итд.). Изражена потреба за језичком економијом у информативним жанровима (вестима, извештајима и сл.) и садржај у њима налагали су потребу да се место описних конструкција (Житель Жоржтавнске НС 1814/935) често граде етници (Жоржтавнцы НС 1814/935), што је понекад код новинара изазивало и творбене недоумице, па одговарајући облик изостаје: Она почитую жительи Кавкасски, Арапи, Монголи, Перуанцы, Негри и Бурети HC $1816 / 905 .{ }^{11}$

6.2. У творби етника најпродуктивнији је творбени модел са суфиксом -ац: Тулонцы СВ 1793/250, Лондонцы СВ 1794/341, Веронесцы НС 1814/135, Нидерландцы НС 1814/421, Вестминстераца НС 1817/137, Бостонцы НС 1814/899, Балтиморцы НС 1814/900, Филаделфцы НС 1814/900, Индїянцы НС 1817/228, Манчестрца НС 1817/244, Франкфуртаца НС 1817/253, Монтевиденцы НС 1817/284, Сан-Маринаца НС 1817/672, Вратиславцы (Бреславцы) НС 1817/548, Мошоньцы НС 1818/356, Пожунцы НС 1819/545 итд. На месту суфикса -ац у многим примерима данас је друкчији суфикс: Шотландцы СВ 1794/321, Хамбургцы НС 1814/90, Норвегцы НС 1814/205, Паризцы НС 1814/361, Исландцы НС 1817/246, Мадридацъ НС 1817/247, Ново-Сееландцыма НС 1817/603, Салцбургцы НС 1818/260, Горньо-Канадаца НС 1819/451 итд.

Утиску о високој фреквенцији овог суфикса доприносе и његове проширене варијанте, на пример: а) -анац (Молдованци СН 1791/28, Амерїканцы СВ 1794/219, Талїанцы НС 1814/101, Тосканцы НС 1814/102, Брестанаца НС 1814/929, Пештанаца НС 1815/456, Белгїанцы НС 1815/544, Елбанцы НC 1815/874, Трстанце НС 1816/79, Либїянцы НС 1819/16, Вандїянцы НС 1815/491, ${ }^{12}$ Хановеранцы НС 1819/80, Сїцїлїанцы НС 1814/1158, Мексиканцы НС 1816/803), б) -ејаи (Европеацъ НС 1817/283), в) -ијанаи (Липсїанцы

${ }^{10}$ Под примере фонетског колебања могао би се подвести и пример: Салонику НС 1816/623 : Тесалоникъ НС 1818/631.

${ }^{11}$ Етници грађени моционим суфиксима неупоредиво су ређи у корпусу: Швайцеркинђ НС 1814/357, Енглезскинь НС 1816/125, Шотландкиня НС 1816/395, Спанїольке НС 1818/282 и сл.

${ }^{12}$ Уп.: Земля сама, зовома Вандїа НС 1815/511. 
НС 1814/1012, ${ }^{13}$ Нансїянацы НС 1816/687). Други домаћи суфикси у творби етника неупоредиво су ређи, попут суфикса -ан у Аустријан (Аустрїанъ НC 1813/136, Аустрїани НС 1815/453) и Перзијан (Перзїяна НС 1817/252), -ин у Турчин (Турцы СВ 1794/334) или -јанин у Млечанин, Љубечанин, Цариграђанин, Римљанин, Хамбуржанин (Млетчани НС 1815/311, Любечана НC 1816/423, ${ }^{14}$ Цариградьане НC 1818/271, Римляна НС 1818/686, Хамбуржана НС 1819/396).

6.3. Тежња ка вернакуларизацији етника видљива је у потискивању облика странога порекла. Тако се, на пример, етници са суфиксом -ез, италијанског порекла, сасвим ретко јављају без творбених конкурената, као у примерима Англез/Инглез/Енглез (Англези СВ 1793/243, Англезе СВ 1794/52, Англези СВ 1794/164 : Инглези НС 1814/62 : Енглезъ НС 1816/610, Енглези НС 1817/146, Енглези НС 1818/176), Генуез (Генуези СВ 1794/316) или Пијемонтез (Пїмонтези НС 1814/102). Творбено посрбљавање ових изведеница видљиво је у многим примерима: а) Холандез : Холандаи (Холландези СВ 1794/164, Холландези НС 1814/71, Холландези НС 1818/176 : Холландцы CВ 1794/258); б) Данез : Данаи (Данези НС 1813/65 : Данцы НС 11814/396); в) Јапанез/Јапонез : Јапанаи (Япанези НС 1818/183 : Японези НС 1818/191: Яапанаца НС 1814/999, Яапанцы НС 1814/999); г) Ирландез : Ирландаи (Ирландезъ НС 1814/422, Ирландеза НС 1818/219 : Ирландацъ НС 1816/591); д) Шотландез : Шотландаи (Шотландезъ НС 1814/422 : Шотландцы СВ 1794/32, Шотланцы НС 1816/453); ђ) Непулез : Неаполаи : Неаполитанац (Непулези НС 1814/1175 : Неаполцы НС 1814/942 : Неаполитанаца НС 1814/284). Именица Чинез (Чинези НС 1818/183) често је у контактној позицији са именицом Китајаu: Китайцы (Чинезы) НC 1815/13, Китаяцъ (Чинезъ) НC 1816/492, Китайцы (Чинезы) НC 1817/163, Китайцы (Чинези) НС 1818/576. Именица Албанез је честа у НС (Албанеза НС 1813/173, Албанеза НC 1815/728, 1031, Албанези НС 1819/563), али јој у контактној позицији конкурише именица Арнаутин: Арнаути (Албанези) НС 1819/563. На исти начин конкуришу и облици Мајландез и Миланащ: Миланцы (Майландези) HC $1814 / 88$.

Страни облик Португиз директно је посрбљен додавањем српског суфикса у реткој форми Портигизаи (Португиза НС 1813/2, 9, Португизи НС 1813/18, Португизи НС 1814/147, Португиза НС 1816/646, Португиза НС 1817/276, Португизи НС 1818/201 : Португизацъ НС 1813/136), али овим формама додатно конкурише и облик Португалаи (Португалцы НС 1814/999, Португалцы НС 1818/176). Облик Алгијер (Аггїеры СВ 1794/397) потиснут је обликом Алгираи (Алгирце НС 1813/174), па облик Швајцер (Шваицери СВ 1794/90, Швайцери НС 1817/212), преузет из немачког језика са истим завршетком -ер, остаје посве усамљен у грађи као постојан.

6.4. При именовању познатих, мање познатих и непознатих држава, војводстава и области са различитих континената новинари су се трудили да

\footnotetext{
${ }^{13}$ Мотивни облик је Липсик.

${ }^{14}$ Мотивни облик је Љубека.
} 
постигну системност. Отуда доминација суфикса -ијa, ${ }^{15}$ раширеног и под утицајем руског и немачког језика (Клајн 2003: 235), и, условно речено, суфикса -ска у поимениченим облицима придева ${ }^{16}$. Изведенице са овим суфиксима често су конкурентне: а) Швеција и Шведска (Швецїа СН 1792/266, Швецїа СВ 1792/27, Швецїа СВ 1794/192,: Шведске СН 1791/38, Шведска СВ 1794/75, Шведска СВ 1794/223, Шведска НС 1817/195); б) Италија и Талијанска (Італїа СН 1792/342, Їталїа СВ 1792/7, Італїа СВ 1793/14, Италїе HC 1814/544, Италїа НC 1814/585: Талїанска СН 1791/63: Талїанска НС 1814/573); в) Франција и Франиуска (Францїа СН 1792/238, Францїа СВ 1792/7, Францїа СВ 1793/15, Францїа НС 1818/519 : Французка СВ 1792/23, Французска НС 1813/9, Французска НС 1815/30); г) Норвегија и Норвешка/Норвегска (Норвегїе СВ 1794/108, Норвегїю НС 1813/15: Норвежска НС 1813/20, Норвежску НС 1813/20 : Норвегска НС 1817/235); д) Саксонија и Саксонска Саксонїи НC 1813/3 : Саксонска НC 1813/66 Саксонска НC 1817/243, Саксонска НС 1818/267; ђ) Белгија и Белгијска (Белгїа НС 1814/685 : Белгійска НС 1814/588, 792, Белгійска НС 1818/372) и др.

Очита је тежња новинара да се број примера назива држава без ових суфикса (нпр. Украине СН 1791/29, Китай НС 1816/629, Сенегала НС 1817/161, Марокко НС 1815/471, Фесь и Марокко НС 1817/211) смањи. Отуда се оригинална именовања посрбљавају и тиме уводе у систем, што узрокује још занимљивију конкуренцију двају или чак трију облика: а) Португал : Португалија : Португалска (Португаль НС 1818/59 : Порт8галїа СН 1792/238, Португалїа СВ 1794/163, Португалїю НС 1813/8, Португалїомъ НС 1818/114 : Португаллской НC 1814/256, Португаллска НС 1816/176, Португалска НС 1817/162, Португалскомъ НС 1818/237); б) Молдава : Молдавија : Молдавска (Молдава СН 1791/28 : Молдавїи СН 1792/343, Молдавїи НС 1814/217, Молдавїи НС 1814/217 : Молдавска НС 1819/465); в) Денмарк : Данија : Данска (у Денмарк8 CH 1791/38, Денмаркъ СН 1791/30, ${ }^{17}$ : Данїа СВ 1794/7, Данїа CB 1794/172: Данска НC 1813/219, Изъ Данске НС 1813/192, Данской НС 1814/66, Данска НС 1817/246); г) Енгланд : А(н)глија : Енглеска (Енгланд СН 1791/34 : Англїа СН 1791/45, Англїа СВ 1793/19, Агглїа СН 1792/53 : Енглезска НС 1817/137); д) Холанд : Холандија : Холандска (Холанда СН 1792/38 : Холандїи СН 1791/72, Холландїи СВ 1792/54, Холландїа СВ 1792/55, Холландїа СВ 1794/112: Холландска НС 1814/63, Холландску НС 1817/548,

\footnotetext{
${ }^{15}$ Појам суфикс овде је схваћен у ширем значењу које му даје Клајн (2003: 235): Валахїа CH 1791/7, СН 1791/17, Галицїа СВ 1794/230, Британїи СН 1791/41, Германїа СН 1792/135, Італїа СН 1792, 342, Хунгарїа СВ 1793/17, Хелвецїа СВ 1794/87, Аустрїа СВ 1793/25, Борусїа СВ 1794/220, Каталоній СВ 1794/242, Россїа НС 1814/609. У правој деривацији имамо га у: Тошканїе СН 1791/63 (: Тоскана), новой Сееландїи НС 1817/603 (: Нови Зеланд).

${ }^{16}$ УП.: Праиске СН 1791/25, Т8рска СН 1791/36, Маћарска СВ 1794/211, Штайерска НС 1814/1060, Неаполїтанска НС 1814/655, Тїролска НС 1816/309, Польска НС 1817/164, Выртембергска НС 1817/172, Турска НС 1817/173, Чешкой НС 1817/292, Баварска НС 1817/244, Баденска НС 1818/769, Тїролска НС 1819/257, Хессенска НС 1819/328, Финландске НС 1819/385, Насавска НС 1819/427, Олденбуржка НС 1819/468, Выртембержка НС 1819/497, Дармштатска НС 1819/498, Моравска НС 1819/585, Мекленбуржка НС 1819/705 итд. Због проблема основе творбено су занимљивији примери: Хановеранска НС 1819/617, Неаполитанска НС 1819/464.

${ }^{17}$ Али у тексту под овим насловом: Данскїи Дворъ.
} 
Холландской НС 1818/731); ђ) Нидерланд : Нидерландија : Нидерландска (Нидерландъ СН 1791/35, Нидерландъ СВ 1792/23, Нїдерландъ СН 1792/53, Нидерландъ СВ 1794/89, 258 : Нидерландїа СН 1792/310 : Нидерландска НС 1814/640, Нидерландска НС 1817/139, Нидерландска НС 1818/175); е) Шотланд : Шотландија : Шотландска (Шотланду СВ 1794/341 : Шотландїю НС 1815/706 : Шотландске НС 1815/1000); ж) Ирланд : Ирландија : Ирландска (Иррланду НС 1814/774 : Ірландій СВ 1794/204, Иррландї НС 1814/642 : Ирландска НС 1814/885, Ирландска НС 1816/145); е) Шваји : Швајиерска (Швайцъ СВ 1794/239, 248, Изъ Шваица СВ 1794/102 : Швайцерскомъ СВ 1793/238, Швайцерска СВ 1794/239 Швайцерска НС 1817/170, Швайцерска HC 1818/163); ж) Јапан: Јапанија (Япана НС 1817/247, У Япану НС 1818/480 : у Япанїю НС 1818/191, 192, у Япанїи НС 1818/191); з) Хина : Хинезка (Хина НС 1814/764 : Хинезска НС 1814/699) итд.

6.5. За новинарску стилистику занимљиви су примери у којима је облик условљен позицијом у тексту, тј. примери коегзистенције различитих облика онима у наслову и остатку текста у НС. Док се у устаљеним насловима налазе само имена држава у форми поименичених придева, у тексту се појављују напоредне форме са крајњим -ија: Спанска : Спанїи НС 1814/589, Енглеска : Англїа НС 1818/114, 124, Француска : у Францїи НС 1818/182, Енглеска : у Англїи НС 1818/186.

7. Лексичка колебања. Велики значај за лингвокултуролошка истраживања имају и примери лексичке конкуренције онима различитог порекла. Три примера добро илуструју оваква лексичка колебања: а) Чифутин : Жидов : Јеврејин (Чиф8ты СН 1792/80 : Жидова СВ 1793/40 : Євреи (Чифути) НС 1814/482); б) Вијена : Беч (Въ Вїєннь СН 1791/6, Вїенна СВ 1792/13, 49, Вїена НC 1817/147 : Беч8 CH 1791/32, Бечу СВ 1792/50, Бечъ СН 1792/365, Бечъ СВ 1794/60, Бечу НС 1818/174); в) Цариград : Константинопољ (Цариградъ CH 1791/11, Цариградъ СН 1791/58, Цариградъ СВ 1794/228, Цариграда НС 1817/283 : Константїнополь СВ 1794/46, Константїнополя СВ 1794/76, 333).

8. Контактна позиција онима. Упркос поменутој потреби да се сажме текст, новинари често наводе, попут друге лексике (Милановић 2013), и ониме у контактној позицији, који не доприносе економичном изразу, ${ }^{18}$ али имају битне функције. Неретко су у питању различита именовања истог онима у страним језицима: Милана (Майланда) НС 1814/80. У напоредним облицима огледају се и језичке недоумице у епохи без прописане лексичке норме: Чиномъ (Китаемъ илити Хїномъ) НС 1814/911, Китай (Чина) НС 1817/171, Чина (Хина China) НC 1818/183, Китай (Чина) НC 1818/369 и сл. Најзанимљивији су, међутим, примери у којима се огледа панславизам Д. Давидовића и Д. Фрушића у НС, који наглашено указују на словенска именовања која су постојала напоредо са несловенским: Клагенфурть (Целовецъ) НС 1813/48, Гданска (Данцїга) НС 1813/49, Дубровникъ (Рагуза) НC 1814/104, ${ }^{19}$

\footnotetext{
${ }^{18}$ Уп.: На рьки є Висли (Вайхсли) твердыню Гданскъ (Данцїгъ) съ 1300 топова, твердыню Замостъ (Замоскъ) са 130, Моддлинъ са 140 топова изгубила НС 1814/36.

${ }^{19}$ УП.: Рагуза СН 1791/8.
} 
Венецїа (Млетке) НС 1814/130, ${ }^{20}$ Карловцу (Карлштадту) НС 1814/743, Вратислава (Бреславе) НС 1814/957, Лвовъ (Ламбергъ) НС 1814/962, Сибиню (Кронштадту) НС 1814/966, Бемска (Чехска) НС 1814/1132, у Вратиславъ (Бреславе) НС 1815/900, у Горицу (Герцъ) НС 1816/359, градъ Любека (Лыбекь) НС 1816/422, у Липско (Лайпсикь) НС 1816/455, Любляну (Лайбахъ) НС 1817/653; у Рњку (Фїюму) НС 1818/250, у Задаръ (Зару) НС 1818/272, Чеси (Бемцы) НС 1818/228 итд. Очито је да бечка цензура није прогањала оваква лексичка решења у НС.

9. „Превођење” онима. Познати су примери посрбљавања страних имена, попут енглеског Елизабет $(a)$ у (J)елисавета (кральице Елисавете НC 1818/123) и сл. Још драстичнији пример вернакуларизације онима представља њихово делимично или потпуно превођење на српски језик: село Велико-Бееренъ (Gros-Beeren) HC 1813/80, Лавобрегу (Loewenberg) HC 1813/83, Лавобрега (Левенберга) НC 1813/88, Куряковца (Волфсберга) НС 1813/88, Тьелавцу (Rachlenberg) НС 1813/88, Новоградъ (Найштадть) НС 1813/238; острова Тринидада (троице) НС 1817/257, Новога Іорка НС 1819/99 и сл.

10. Потреба за речником. Надамо се да сви наведени примери указују да би Речник онима у славеносрпском језику имао не само лингвистички но и културолошки значај. Практична корист од њега огледала би се у бржој детекцији (препознавању) онима у старим текстовима, што би олакашало њихово разумевање, али и спречило типичне грешке, на пример, приликом приређивања и потенцијалног исправљања „штампарских грешака” (нпр. Мадрит, Букорест и сл.). Такође, спречило би се и њихово погрешно тумачење ван контекста: тек из текста види се да је Индијанаи становник Индије (данашњи Индијац), и сл. Кључно питање је да ли вршити потпуну ексцерпцију или се фокусирати на дистинктивне облике у односу на данашње јер оба решења имају своје предности: први даје потпуну слику у самом језику и епохи, други је практичнији, економичнији и лакши за израду.

Ради функционалности, а услед обиља грађе, овај би речник морао: а) донети транскрибоване одреднице и игнорисати при томе графематско-ортографска колебања која су ирелевантна за корисника, али их треба нагласити селекцијом примера. Тако у речнику, на пример, одреднице Нидерланд и Прајска треба да буду илустроване примерима са различитим графијско-ортографским решењима (Нидерландъ СН 1791/35: Нїдерландъ СН 1792/53; Праиске СН 1791/25, Прайска СВ 1794/11, Прайзска НС 1817/136 и сл.); б) смањити број информација у речничком чланку на минимум: као „дефиницију” требало би дати савремени облик или сажету конструкцију (нпр. у случају етника житељ/становник/држављанин и сл. + оним); в) у речничком чланку упутити на све конкурентске облике: фонетске, морфолошке, деривационе, лексичке, без давања предности билом којем облику; г) донети већи број репрезентативних примера из различитих извора, поређаних хронолошки; ${ }^{21}$ д) регистровати и нагласити прве потврде у корпусу; ђ) преузети и, по

\footnotetext{
${ }^{20}$ Уп. други редослед: изъ Мльтака (Венецїе) НС 1817/720, или само: Мльтке НС 1817/540.

${ }^{21}$ Добро селектовани примери истовремено показују и графијско-ортографски развој.
} 
потреби, допунити публицистичким делима корпус и техничка решења из Речника славеносрпског језика, у циљу постизања комплементарности. Ауторе би, наравно, морао сачињавати интердиспиплинарни тим, у којем би били лексикографи, историчари језика, историчари и географи.

11. Закључци. На посебан значај и функцију онима у новинарским текстовима из слс. епохе указује и њихово наглашавање спационираним писањем у штампи. Уредници су маркирали ониме као специфичан лексички слој који је неретко био сасвим нов и непознат и њима самима и читаоцима. Непреврела језичка ситуација условила је бројне варијације, које ћемо у закључку додатно нагласити најрадикалнијим примерима:

А) Држава коју данас именујемо као Шианија именована је у СН, СВ и НС на шест начина: а) Хишпанија (Хишпанїа СН 1791/63), б) Исnанија (Іспанїа 1794/170 Іспанїа НС 1818/519, Іспанїи НС 1819/563), в) Иипанија (Ишпанїи СН 1791/16, 2, Ишпанїа СН 1792/302), г) Cnaнија (Спанїа НС 1813/29, Спанїи НС 1813/3, Спанїа НС 1817/161), д) Спанска (Спанске НC 1814/39, 52, Спанска НС 1814/577), ђ) Шnанија (Шпанїа СН 1792/40, Шпанїа СВ 1793/18, Шпанїа СВ 1794/57).

Б) Становник наведене државе именован је пак на седам начина: а) Ижпанац (Ишпанцы СВ 1794, 167, Ішпанцы CB 1794, 170), б) Шпаниолаи (Шпанїолцемъ СВ 1794/282, Шпанїолцы СВ 1794, 283, 290, Шпанїолце НС 1818/130), в) Шпаниол (Шпанїола СВ 1794/78, Шпанїоле СВ 1794/291, Шпанїоли СВ 1794/296), г) Шиағур (Шпанюра СН 1791/41), д) Спаниолаи (Спанїолцемъ НС 1813/7; Спанїолацъ НС 1813/136, Спанїолаца НС 1814/52, Спанїолцы НС 1816/43, 163, Спанїолце НС 1818/150), ђ) Спаьолац (Спаньолаць НС 1814/945, Спаньолацъ НС 1814/76, Спаньолаца НС 1814/892, Спаньолцы НС 1816/406, 437), е) Спағол (Спаньоллу НС 1814/934).

В) Седам различитих облика има и данашњи оним Барселона: а) Барцุелона (Барцеллони СВ 1793/260, Изъ Барцелоне СВ 1794/198, Барцеллони НС 1815/183); б) Вариелона (Изъ Варцеллоне СВ 1794/186, Варцеллоне НС 1814/27, Варцелону НС 1815/427); в) Варселона (Варселоне НС 1817/229, Варселоне НС 1818/121; г) Варсељона (Варсельоне НС 1818/180); д) Варчелона (Варчелонне НС 1816/291); ђ) Бариелон (Изъ Барцелонна СВ 1794/206); е) Варцелон (изъ Варцеллона СВ 1794/223).

Г) Сличну судбину у слс. језику имао је и Лисабон, који има четири форме: а) Лисабон (изъ Лисабона СВ 1794/163), б) Лисавон (У Лиссавону НС 1817/245, Лисавонъ НС 1819/42), в) Лизабон (Лізабонскаго СВ 1794/199); г) Лисабона (изъ града Лїссабоне СВ 1794/242).

Није тешко закључити да су и оними делили судбину друге славеносрпске лексике: њихову егзистенцију у новинарским текстовима пратили су конкуренција и коегзистенција облика, неустаљеност на графијско-ортограф- 
ском, фонетском, морфолошком, деривационом и лексичком плану. Анализа сасвим ограниченог корпуса показала је огромно варирање.

Обличком колебању суштински су доприносили различити фактори. Немогуће је, наиме, у праћењу развоја форми онима у првим српским новинама искључити две значајне социолингвистичке и стилистичке чињенице: a) славеносрпски језик, без кодификације и без строге лексичке норме, радо је упијао све конкурентске облике, нарочито у публицистици (Милановић $2013)$; б) страни оними улазили су у овај језик углавном посредством страних језика на којима су штампане тадашње утицајне новине и друга литература, најчешће преко немачког језика бечке штампе.

Анализа примера у раду указала је и на синхронијска и на дијахронијска колебања: многе форме онима међусобно конкуришу у истом тренутку и у истим новинама, али се истовремено уочавају и одређене блаже тенденције, нпр. да се устале форме етника налик на српске. Промена форме онима често сведочи о генералним лексичким процесима у славеносрпском језику и потврђује их. Тако се постепена лексичка вернакуларизащија огледа и различитим процесима везаним за форму онима: њихово посрбљавање одговарајућим суфиксима (Холанд > Холандија, Португал > Португалска, Холандез $>$ Холандац, Португиз > Португизаи и Португалач). Облик онима је понекад био условљен и позицијом у тексту, па се једна форма јавља у наслову, а друга у остатку текста (Спанска : Спанија, Енглеска : Англија, Франиуска : Франција). Навођење конкурентских форми онима у контактној позицији (Гданск : Данциг, Лвов : Ламберг, Целовец : Клагенфурт) сведочи и о панславизму уредника НС.

Што је старији период и што је временски захват већи, број варијаната расте. Зато је у СН и СВ (1791-1794) варијаната заправо сразмерно више него у НС (1813-1822), али су НС излазиле много дуже и текста је неупоредиво више, као и њихових аутора тј. преводилаца, па је и број варијаната у њима зато растао. Колебања око форми онима наставила су се у смањеном интензитету и у Вуковој и вуковској епохи, а трају у појединим примерима (Португалија : Португал, Корејанаи : Корејаи и сл.) и данас.

Стога је прави задатак историјске стандардологије да утврди како се дошло до данас устаљених форми онима страног порекла, чему би суштински могао допринети одговарајући дијахронијски речник. У том настојању треба релативизовати потребу за утврђивањем што прецизније хронологије развоја облика због бројних синхронијских варијација (које нису ретке ни у истом тексту), као и питање порекла онима због језика посредника, којих може бити и више у ланцу преношења вести из новина у новине и од уста до уста. 


\section{ЛИТЕРАТУРА}

Албијанић 1979: Александар Албијанић, Деклинација страних личних имена у 'Новинама српским' (1813), Зборник Матице српске за филологију и лингвистику, XXII/1, 111-123.

Албијанић 1984: Александар Албијанић, Страна имена и топоними у неким српским текстовима XIX века: кратак осврт на Давидовићеве 'Новине српске' (1814), Научни састанак слависта у Вукове дане, 13/2, 67-75.

Караџић 1968: Вук Стефановић Караџић, О језику и кьижевности I, Сабрана дела Вука Караџића, књига дванаеста, Београд: Просвета.

Клајн 2003: Иван Клајн, Творба речи у савременом српском језику. Други део: Суфиксаиија и конверзија, Београд - Нови Сад: Завод за уџбенике и наставна средства - Матица српска - Институт за српски језик САНУ.

Милановић 2013: Александар Милановић, Језик весма полезан, Београд: Друштво за српски језик и књижевност Србије.

Милановић 2014: Александар Милановић, Језик Јована Суботића, Београд: Чигоја штампа - Филолошки факултет у Београду.

ОС 2017: Речник славеносрпског језика : огледна свеска (прир. И. Бјелаковић, И. Цветковић Теофиловић и А. Милановић), Нови Сад: Матица српска.

ПМС 2014: Митар Пешикан, Јован Јерковић и Мато Пижурица, Правопис српскога језика, Нови Сад: Матица српска.

hopић 2008: Божо Ћорић, Творба именииа у српском језику, Београд: Друштво за српски језик и књижевност Србије.

Шћепановић 1997: Михаило Шћепановић, Ономастичка терминологија и норма, у: Трећи лингвистички скуn „Бошковићеви дани”, Подгорица: ЦАНУ, 215-223.

Шћепановић 2003: Михаило Шћепановић, Српска ономастичка терминологија, Свет речи, 15-16, Београд, 14-16.

Aleksandar M. Milanović

NAME WORDS OF FOREIGN ORIGIN IN SLAVONIC SERBIAN

Summary

The paper investigates the development and adaptation of name words of foreign origin in journalistic texts written in Slavonic Serbian. Special attention is paid graphemic, orthographic, phonological, derivational and lexical volatility of such forms. Co-existing and rival status of many examples are manifested on sociolinguistic and stylistic level. Due to the exceptional variety of a high number of collected examples, the author proposes that a diachronic dictionary of name-words in Slavonic Serbian (1750-1850) be compiled.

Key words: Slavonic Serbian, name-words, ethnonym, vernacularization, doublet, journalistic style, pan-Slavism, diachronic dictionary of name words. 